\title{
Childhood
}

\section{The greenhouse effect: Multispecies childhood and non- innocent relations of care}

\begin{tabular}{|r|l|}
\hline Journal: & Childhood \\
\hline Manuscript ID & CHD-18-0072.R1 \\
\hline Manuscript Type: & Original Manuscript \\
\hline Keywords: & $\begin{array}{l}\text { child-animal relations, multispecies childhood, multispecies ethnography, } \\
\text { zoo, bag lady storytelling }\end{array}$ \\
\hline Abstract: & $\begin{array}{l}\text { This article examines the relations between human children and other } \\
\text { than human animals in a multispecies ethnographic study conducted in } \\
\text { an unofficial educational zoo established in a greenhouse in a lower } \\
\text { secondary school. The specific focus is on the practices in which the } \\
\text { students become responsible carers of animals. The analysis employs the } \\
\text { theory of care (de la Bellacasa) and a storytelling approach (Haraway) to } \\
\text { develop the concept of multispecies childhood and to offer ways to } \\
\text { account for the complexities of lives shared across species. }\end{array}$ \\
\hline
\end{tabular}

\section{SCHOLARONE Manuscripts}




\title{
The greenhouse effect: Multispecies childhood and non-innocent relations of care
}

\begin{abstract}
This article examines the relations between human children and other than human animals in a multispecies ethnographic study conducted in an unofficial educational zoo established in a greenhouse in a lower secondary school. The specific focus is on the practices in which the students become responsible carers of animals. The analysis employs the theory of care (de la Bellacasa) and a storytelling approach (Haraway) to develop the concept of multispecies childhood and to offer ways to account for the complexities of lives shared across species.
\end{abstract}

Keywords: child-animal relations, multispecies childhood, multispecies ethnography, morethan-human, education, zoo, bag lady storytelling

We are on our way to another day of fieldwork.

Inside the school building, we cross the entrance hall.

One knows these kinds of secondary school entrance halls by heart:

they are so familiar, always similar.

But when we open the greenhouse door, another world overwhelms:

scents and smells from blooming and decaying plants,

bright lights,

cries, shouts, sounds and chirps,

accompanied by smaller rustles and the humming sound of a humidifier.

The human kids spend their break in the greenhouse.

Some of them have gerbils in their hands, some of them are cleaning the floor, feeding rabbits, or sitting on the benches, jostling each other, flirting and joking, checking their mobile phones once in a while. We hurry to go inside. ${ }^{1}$

\section{Opening the door to the greenhouse}

\footnotetext{
$1 \quad$ We present the empirical part of the study in the format that we ended up writing together while doing fieldwork. This storytelling, influenced by Haraway (2004), can be seen as working in-between field notes and analysis and disturbing coherent and linear ways of reading. It facilitates rhizomatic writing and thinking in the spaces between the lines, and makes the stories accessible for listeners and other storytellers, including the young participants of the study.
} 
How do children form and sustain relations with other than human animals ${ }^{2}$ ? Within a larger project on child-animal relations, we came to explore this question in a Finnish lower secondary school that has a greenhouse located in the building's atrium. This is the biggest educational greenhouse in the Nordic countries, complete with all the technology required to create a subtropical climate in the middle of the surrounding arctic environment. First used as a rescue facility for homeless pets, the greenhouse has evolved into an unofficial educational zoo inhabited by both rescue animals and purchased ones. The school is located in a disadvantaged, largely immigrant-background suburb. The establishment of the greenhouse was possible in the early nineties, when municipality allocated the resources for it following the so-called 'positive discrimination' policy.

The greenhouse inhabitants currently include approximately 40 bigger animals such as turtles, rabbits, a parrot, a dove, cockatiels, a green iguana, a water dragon, a corn snake, mice, guinea pigs, gerbils, a rooster and a hen. There are also smaller critters such as stick insects, ants, snails, mealworms and flies. Plants include tropical fruit trees, jacarandas, hibiscuses and more. Some animals are moving around on the floor of the greenhouse, some are in their cages and terrariums, or flying and sitting on beams close to the glass ceiling. The doors of the greenhouse are open to visitors, but there is the inner circle of some 20 students (aged 13-16) who like to spend most of their free time in the greenhouse. These greenhouse kids, as we like to call them, come in the greenhouse first thing in the morning, when it is often still dark, and they stay sometimes until the janitor leaves at eight or nine in the evening. Most of these young people have taken a course during sixth grade to qualify as responsible carers of the animals, and they are mentored by two biology teachers, Armi and Taina. Some of the secondary school students lead so called animal clubs, which are afternoon clubs for smaller children, aged 8-12. Often, we find no adults present in the greenhouse. The young people are spending time there on their own, taking full responsibility over feeding, cleaning and other daily tasks related to maintaining the greenhouse and taking care of the animals.

Our fieldwork took place during the winter months, starting in December and ending in April, spending more or less every Tuesday and Thursday in the greenhouse. Along with getting to

2 Doing multispecies research, we have been challenged to rethink our ways of talking about our research participants as children and animals according to speciest categorizations. The term animal is obviously a culturally charged generalization. In this article, we employ an experimental selection of conceptualizations when referring to humans of young age and representatives of other than human species. 
know the greenhouse kids and the inhabitants of the greenhouse and listening to the stories told, the research became an intense entanglement whose rhizomes reach beyond the walls of the actual research context and the timelines planned. For example, at the moment of writing this article the kids continue to use a WhatsApp group to tell us all the breaking news 'Trio the guinea pig is pregnant!' - as well as to suggest visits to the pet shop and zoo. The lively greenhouse refuses to be only a background for children's actions or human-animalencounters, rather, it became an ongoing provocation to our situated accounts for childanimal relations. It also is because of that place that the non-innocent and complex notions of care (de la Bellacasa, 2017) occupied a central place in our theorising of multispecies childhoods.

With the greenhouse kids and critters in mind, we will now proceed to a short overview of various foldings-together of animals and children across previous childhood research, and the posthumanist body of childhoodnature work, which is our theoretical home. Then we will move on to weaving theories of care in the assemblages involving the children and animals in the greenhouse and present our multispecies narrative approach.

\section{Do children and animals go 'naturally' together?}

Since establishing the notion of nature as separate from and opposed to culture, particularly by the philosophers of the Enlightenment such as Rousseau (1712-1778), children have been seen firmly belonging to the nature side along with animals. This means that the image of the child is idealised and often defined as innocent, pure and entitled to freedom and happiness (Darling and van de Pijpekamp, 1994) but also vulnerable, slow to mature, endangered and at risk of getting corrupted through the dangers of adult society (Taylor, 2011). This romanticised and idealised 'natural' child has been disrupted from two main theoretical perspectives. First, the social constructivist viewpoint rendered 'natural' childhood as constructed, history-specific and man-made (Taylor, 2011). Second, scholars working from posthumanist, new materialist and more-than-human frameworks (Taylor, 2011; Lee and Motzkau, 2011; Rautio, 2013; Malone, 2018) have challenged both essentialising and naturalising childhood discourse and the ways that constructivist accounts diminish the role of environment, time and nonhuman beings into 'the inert scenery against which the humanist adventures of culture are played out' (MacLure, 2013: 659). These scholars have emphasised children's relations to environments and other things and beings, and their networked and 
interdependent existence with them. Prout (2011) wrote about this move as re-attending to 'the excluded middle' referring to the need to abandon dualist thinking altogether something that indigenous philosophies have encompassed for long. Thus, these viewpoints neither group children and animals in a shared category or place them in opposite ones. Rather, they see them always already in relation.

Despite these disruptions, nature-culture dualism has not ceased to influence strongly both commonsense and professional Western views about what a child naturally is, and what is best and natural for a child (Taylor, 2011). This dualism also enables the persistent appeal of risk discourses, strongly commercialised and repeatedly performed in various media, which find threats for the natural and normal condition of childhood in ever new locations.

Milla tells me that her brother is moving out, she will get a room of her own and can have gerbils there.

Her sister still lives home and is allergic, but now the gerbils will be held in a different room and her allergy is not that bad.

This reminds me how Jussi was one day brushing Leo the rabbit. He was all covered with Leo's hair.

'Armi, what do I do?

My English lesson begins and the teacher is allergic to rabbits!'

We all laugh at the situation.

'Maybe you ask the teachers, if there is some kind of a solution', Armi replies.

Later on, Jussi tells me that he cleaned his clothes with tape and was thus able to participate in the lesson.

Our study connects to material and relational ontologies and epistemologies (Deleuze and Guattari, 1987; Barad, 2007) and to the larger animal turn in social sciences (Kirksey and Helmreich, 2010; Pedersen and Pini, 2017). Accordingly, we recognise that rabbits and humans are relational beings emerging from naturecultures, and they can matter to each other beyond human meaning-making. Their lives entangle and affect each other at the level of immune systems and at the level of occurrences such as divorces or employment in complex and particular ways. Relational ontology affects how multispecies inquiry is perceived: it is only through and within relationality, which is ontologically prior, that human and nonhuman animals individuate (Manning, 2013) and come into existence as the specific beingbecomings as they are. Our research thus necessarily starts from our own attachments with relations as analytical units rather than individuals or interactions between individuals (Pickering, 2005). We specifically like to situate our multispecies research in the materialdiscursivity of the more-than-human world (e.g. Haraway, 2016; Pedersen and Pini, 2017). 
We came here to do multispecies ethnography about child-animal relations, but in the greenhouse we lose our efficacy and get indecisive, halted and overwhelmed by strange encounters such as the combination of the dove Romeo and the mechanic humidifier at the center of the ceiling with the label Princess.

Romeo and the other birds enjoy sitting on Princess while it is working, humming and spraying water all over. Sometimes they knock on the machine as if to turn their shower on. The greenhouse birds also like electric wires: they do tricks on them and sleep on them rather than on the wooden sticks hung in the ceilings meant to serve as swings. 'It is not always easy to guess what the birds like to sit on', says Armi.

The processes of becoming are not only rosy and full of positive potential. Withlings can make odd relations to each other, and their becomings intertwine with painful pasts and futures. Somerville (2018) pointed out that contemporary childhoodnature scholars are often taken to places where it is difficult to be in the midst of complexities and tensions where the only solution is to 'stay with the trouble' (Haraway, 2016). To think of beings as becomings or as withlings is to take seriously the potential presence of both joy and suffering in the process of repeating while becoming different (Deleuze and Guattari, 1987). In the greenhouse, we sensitised ourselves to the combinations of technologies and human and nonhuman animals, as well as to the environmentally problematic amount of energy needed 
for maintaining the subtropical climate. Seen this way, the greenhouse is a techno-bio-social laboratory of sorts, filled with affect and attachment but also pressing ethical questions of coliving. Indeed, here the question 'how to care' is not easy to answer (de la Bellacasa, 2017, 7).

Grusin (2015), in his discussion on the 'nonhuman turn', suggests that whereas defining human used to be seen to require making a distinction from other species, human could be instead characterized through their relatedness and indistinction with other than humans. In this article, we ponder this definition in relation to young humans and, specifically, relations of care that they are involved with. In doing so, we once again group children and animals together, but this conflation has gone a long way from Rousseau as it is not in isolation but always grouped with something else in assemblages. As such, it is not idealised as innocent, and it is material as well as discursive while mattering to those involved in complex ways.

\section{Children, animals and care in educational contexts}

The primary distinction between animals and Men, according to Rousseau, was that humans were free agents and had reason, and the task of education was to trigger and govern the use of it. In the light of this legacy, perhaps it is no wonder that education has been among the slowest of disciplines to adopt the critique of human exceptionalism accompanying the animal turn of social sciences (Pedersen, 2010). This is not to say that the alliance between animals and children is not seen as a useful one in education. During fieldwork in schools, we have seen textbooks and other materials filled with animal characters, which are used to make preferred learning goals and behaviours child-friendly (e.g. Burke and Copenhaver, 2004). Moreover, recent years have brought live animals in classrooms as legitimised pedagogic or didactic partners in the form of increasingly popular animal-assisted social and pedagogical practises. These often professionally trained companion animals, such as reading dogs (Friesen, 2010), are assumed to enhance for example learning, responsibility, and empathy (Thompson and Gullone, 2003) and have a positive impact on social relations in the classrooms. In the existing research on child-animal relations at large, it is mainly the usefulness of animals for human children's development or skills that interests (Myers, 2013; for exceptions, see Somerville, 2018). The dominant methodological stance is positivist and quantitative.

In order to maintain the economic resources for our greenhouse, its significance is justified using the above sketched human-centred educational discourse. The school was accepted 
under the title 'Learning from Animals' as a partner in a programme comprising 100 succesful educational innovations, presented on the website, 'the innovation teaches children self-sufficiency and life skills through animal care (. . .)' (HundrEd, 2018). The aims are in line with the existing curriculum in Finland (Finnish National Agency for Education, 2014) in which the ideal student would be self-initiated, innovative and willing to run different collaborative and explorative projects. Here, the capacities of the child are recognised and children are not positioned as innocent or incomplete; also, the animal can be seen as the teacher. What remains, however, is a binary where the animal is on the other side as a facilitator or catalyst, a resource for humans to improve skills and agency.

Accompanying the common worlds pedagogical approach to childhoodnatures (e.g. Nxumalo and Pacini-Ketchabaw, 2017; Taylor and Pacini-Ketchabaw, 2017), we might ask, what would it be to be educated by/through a withling that matters but does not necessarily render itself explicable in humanist terms? Spannring (2015) pointed out a tension between the practises that objectify nonhuman animals while aiming at fostering sustainable futures (see also Taylor and Pacini-Ketchabaw, 2017). He says that the objectifying and commodifying practises, such as animal dissection and holding nonhuman animals in captivity for the sake of human curiosity and learning, may actually intensify desensitisation among students because in them the animal is seen as existing for the humans to explore. This brings us to the central tensions of the greenhouse. While affecting us all deeply and mattering for the children involved, the greenhouse makes us become as parts of multiple reproducings of multispecies relations, including conflicting practises of capture and objectification. It is an ethically and politically ambivalent techno-bio-social assemblage, which has little to do with idealised natural behaviours of neither children nor their nonhuman companions.

It is here that we start to weave theories of care together with the child-animal relations of our study. Care, just like childhood, is as a notion that is rarely understood as anything else but good, beneficial and ethical, in other words, innocent. In the educational context of the greenhouse, the practises of caring that the volunteering greenhouse kids engage in are talked about as the source of responsibility, socioemotional growth and empowerment. The relational ethics of care by Tronto (1993) and the speculative account of matters of care by de la Bellacasa (2017) complicate this one-dimensional picture. Tronto's work highlighted care as a concept that challenges the autonomous self-made individual and prioritises the significance of social relations. Furthermore, this account of care recognised the power relations involved in caring relations, offering a possibility for transforming social and 
political thinking. Bartos (2012) used Tronto's theories when examining children's political agency, arguing that the concept of care opens agency to be analysed as interrelations, particularly with family and the physical environment, rather than solely as a move toward independence, autonomy and individualisation.

Similar to Tronto, de la Bellacasa (2017) used care as a provocation or analytic rather than a pre-defined set of ethical or moral norms. For her, engaging with care can lead inquiry to difficult and troubled places. She reworked the three interrelated dimensions of care presented by Tronto (1993) as follows. First, care is an affective state: to care is to be affected by another, to be emotionally at stake in them in some way. Second, care is an ethicopolitical obligation, and as such often deeply ambivalent and problematic as, for example, feminist research on low-paid caring work has highlighted. Finally, care involves always some kind of practical labour or maintenance. This way it requires more than abstract wellwishing: it includes material involvement whereby also a temporal dimension enters the picture. According to de la Bellacasa (2017), all three interrelated dimensions are needed for a practise to be defined as care. For example, without maintenance work, affectivity does not make it up to care and keeps it closer to a moral intention, to a disposition to care about without putting in the work to care for (Tronto, 1993).

What is central for our thinking about the everyday caring relations in the school greenhouse is the tensions between these three layers that can be read through each other (de la Bellacasa, 2017). Furthermore, we follow de la Bellacasa, among others, in her insistence of a situated approach. To research the relations of care becomes then 'thick, impure, involvement in a world where the question of how to care needs to be posed' (de la Bellacasa, 2017, 6).

\section{Bodies that produce stories that produce bodies}

The greenhouse is a place of stories: stories of its present and former inhabitants and their caretakers, stories in the form of bits and pieces of information found from the internet, and stories in the form of endless dreams and plans concerning improvements and possible new purchases. It is a place where bodies and stories are continuously co-producing each other (Haraway, 2016).

When we first arrive at the greenhouse

I am mesmerised by Sälli, the iguana situated in the centre of the space.

It looks scary, and I am a bit cautious and afraid. I wonder, 
could I befriend him, attune with him?

Then one day I see a former caretaker, now in a different school, going to the iguana. 'Let's see if he still remembers me'.

He approaches from the side and reaches in with his hand.

Sälli moves a little, and his hand goes a little backwards, then approaches again

until he is petting Sälli's skin

'He does remember'.

Our research becomes an ethnography of stories and bodies and their co-becomings. When engaging in multispecies ethnography (Kirksey and Helmreich, 2010), we attend to bodies that are not only human, and we try to attune to stories that are not only within the capacities of our human senses and meanings.

I ask what should I do since I want to know if petting is possible for me as well. He tells me to try it.

Soon I find myself petting Sälli's cool skin.

It has its eyes closed.

I feel and see how he breathes, our breathing making a syncopating rhythm.

$\mathrm{NN}$ comes to pet as well, and when she finishes,

Sälli opens his eyes and gives a look we interpret as meaning to continue.

NN continues and Sälli closes his eyes again, looking pleased.

Haraway (2004) has elaborated on Ursula LeGuin's carrier bag theory of fiction into a narrative strategy called bag lady storytelling. This storytelling practice, in her words, proceeds by 'pitting unexpected partners and irreducible details into a frayed, porous carrier bag. Engaging halting conversations, the encounter transmutes and reconstitutes all the partners and all the details. The stories do not have beginnings or ends; they have continuations, interruptions and reformulations - just the kind of survivable stories we could use these days' (127-128). Our methodology seeks to join the lives of children and animals in the greenhouse, which we could understand with Haraway as kind of a bubbling and boiling 'compost' (2016, 97), as listeners of stories and as storytellers ourselves. Weaver and Snaza (2017) suggested that to be able to listen to non-human beings' voices and habitats, humans have to enter more-than-human worlds as students, not as master storytellers or superior species. What would it be to tell new stories based on such listening? They might be understood as new versions - particular stories of multispecies encounters, accounts, perspectives and explanations - that coexist with other versions of the same event, not all of which are solely human (Despret, 2016). Despret coined the term visiting to embrace the 
polite and respectful approaching of lives and knowledges unknown to us. For her, the task of research is 'to reconstruct, to fabulate, in a way the opens other possibilities for the past in the present and the future' (178). This holds open the possibility that 'surprises are in store, that something interesting is about to happen', which only takes place through letting those one visits intra-actively shape what occurs. 'They are not who/what we expected to visit, and we are not who/what were anticipated either' (Haraway, 2015, 6).

Doing multispecies ethnography and storytelling puts us in need to erase much of the anthropocentric methodologies previously known to us, and to experiment with alternative ways of sensitising us, or 'attuning and attending' (Rautio, 2017), to multispecies relations. The above discussed educational discourses of children, animals and care are both reinforced and disturbed in the greenhouse. In some moments, like when the children take an egg from the chicken's nest and gather around the microscope to see if it is fertilised, the vertical relation (Duhn and Quinones, 2018) of looking at animals as objects is strongly present. Other times, a more horizontal relation emerges, for example when Pertti talks and walks with the hen and the rooster (repeatedly uttering 'koot-kot-kot'), attuning to and becoming with her nonhuman companion whose responsible carer she has been for some years already. These encounters force us to think, and affect us, and we find ourselves retelling them in talks with the biology teacher Armi, recognising their force and intensity: it is stories and bodies together that produce withlings. Often these stories have the capacity to challenge the primacy of the human brain as 'the seat of meaning-making' (Duhn and Quinones, 2018: 4). 'There is something organic', says Armi. And she often halts in wondering and not finding an explanation to what she sees. Her mention of 'organic' leads us to talk about Haraway's compost and the possibility of changing through a proliferation of all sorts of nonhierarchical relations of difference: mutations, contagions, and infections (Sampson, 2012).

\section{The death of a gerbil - care-time}

During a break at the animal club, The smaller and bigger children are sitting on sofas outside the greenhouse and having snacks.

Esteri, one of the former secondary school students; is also present.

She still comes to the school to lead the club for the smaller ones even though she already goes to high school. Lisa, her coleader, comes from the greenhouse. 'Esteri, here is Mimukka'. 
She carries one of gerbils in her palms, gives her to Esteri, and says, 'She is kind of old now.

She is not doing all the funny and cute tricks she used to anymore, and you can feel her spine through the fur'.

Lisa also thinks that the ones who currently are Mimukka's responsible carers do not spend enough time with her.

Esteri takes the little gerbil against her body, and she starts to move across her neck and back, in and out her big woollen scarf. Esteri speaks softly and caresses the little creature,

'Mimukka is the first gerbil that I have seen being born'.

Everyone is gathered around them.

A moment of silence together.

The small kids look at Esteri, almost grown-up, with admiration.

The next time we come to the greenhouse, we hear that Mimukka is dead.

One morning, its eyes were swollen and it couldn't move,

the decision about euthanisation was made quickly.

When we meet Esteri, I ask how she had felt hearing about Mimukka's death.

'I was not there', she says silently.

The story about Mimukka is one of the stories that have stayed with us, forcing us to think. Care has brought them together - the elderly gerbil coming close to its death, the young adult human, already continuing her life outside the school and the smaller children who come to the animal club to become carers for the animals. A story about momentarily conjoined lives where time, life and death remain open for wondering. Practises of care become transmitted and contaminated in encounters like this. But just like Tronto (1993) and de la Bellacasa (2017) theorised, the dimensions of care do not sit together in harmony. As soon as the affective dimension of the shared life histories of the young human and her little companion animal is there, the material and ethico-political dimensions also emerge. They are evoked in the form of questions about care as spending enough time with a caged animal, and, ultimately, in the dilemma of deciding about lives and deaths.

The sizzling and glowing liveliness of the greenhouse is created largely through the multispecies collidings and conjoinings of different temporalities. While Esteri was able to witness the life of her nonhuman companion Mimukka from birth to death, some of the turtles in the greenhouse were older than us. De la Bellacasa drew on feminist thinkers when talking about the centrality of temporal matters in care: 'Anybody who has been involved in caring for children, pets, elderly kin, an allotment, cells in a petri dish, knows that the work of care takes time and involves making time of an unexceptional particular kind' (2017: 206). Her concept care-time embraces the affective, embodied and never neutral aspects of time. In 
relation to science and education discourses that emphasise clearly pronounced results and efficacy, this concept is strikingly political, as the labours of everyday mundane maintenance, repetitive work and task reiteration usually remain imperceptible from the perspective of these domains.

Lisa's suspicion about the present carers of Mimukka not spending sufficient time with her opens up a huge question: what is good care? It is commonly agreed in the greenhouse that the carers should spend time with their caged pets in order to detect signs of stress and illnesses and to monitor their well-being. But to care means to be involved with questions that reach as far as dying and killing. Whereas the anthropocentric educational perspective in its extreme allows making sense of the deaths of pet animals as learning experiences where children learn about loss (Rautio and Leinonen, 2018), attending to care opens up the noninnocence and ambivalence of child-animal relations.

\section{When knowing hurts}

One day the animal club kids are in the greenhouse, sitting on a table and chatting. Paula talks and holds a black gerbil named Chuck in her hands.

While speaking, she inadvertently starts to squeeze the gerbil so hard it cannot move. Chuck bites Paula's hand hard.

The biting goes on and on as the gerbil clamps on to her hand.

Paula yells, 'Help me, what can I do'!

The gerbil stays stuck to her hand for 30 seconds then finally lets go, followed by a blood spill that leaves Paula sobbing. Armi cleans the wound and finds plaster for Paula, telling her that the best caretakers have been bitten by their animals.

Paula is not that sure.

'I will never hold gerbils again, at least not black ones'!

Sometime later, I notice Paula taking Toffee and Chuck from their cage.

She has wrapped her sleeves over her hands in order to pick them up. 'I notice that you use sleeves when handling gerbils'.

'Yes, but sometimes I just take them with bare hands', she replies.

'They sometimes do bite'.

The becoming of the gerbil-with-the human as well as the becoming of the human-with-the gerbil take place in a material and embodied contact zone (Haraway, 2008). In our previous research schools, we did not see children entering such contact zones, as much as they did excursions outside the school in the nearby forest or explored their notions of 'animal' through artistic practise. Within those practises, to know about an animal was equalled to 
being able to situate the animal into a correct species category, to describe the characteristics of the respective species or to be able to tell cultural stories about them. There was no possibility for the animals to respond to the world outside their man-made cultural representations. The knowledge that emerged in that connection certainly did not hurt. The animals dealt with could not look back and make children curious about what the animals could be feeling, thinking and making available (Haraway, 2008). Neither were there attempts to challenge the nature-culture divide, or the vertical relation between humans and animals including objectifying and exploitative practises. In other words, the ethical concerns related to multispecies co-living remained absent.

In the greenhouse, we observed hands taking animals from their cages, stroking them, handing them to other hands, including ours. Here, the animals did not remain mute and still, and neither did the hands handling them. Our mutual becoming within multispecies caring relations also brought different knowledge practises into existence, practises in which knowing could be seen as following de la Bellacasa, 'thick, impure involvement in the world' (2017: 6). Through being able to respond, the animals perhaps become teachers but in another way than described in the HundrEd programme or in the commonplace discourses about children developing through taking care of pets. Might it be possible that the animals as teachers intervene and ask us to listen differently (Weaver and Snaza, 2017) through the bitings, birds refusing to be easily captured and rabbits fighting and avoiding reimprisonment? Understood as emerging in caring relations, knowing is material, affective and temporal engagement. As participants of these kinds of embodied and relational knowledge practises, the children must 'respond to the consequences, and . . . their responses are part of the consequences' (Despret, 2016: 182). Despret wrote that processes of domestication might not be merely unidirectional. This is visible in how caring relations make the participants available to each other in ways that make a difference to them and to those around them. Within these never certain and unproblematic relations, also humans become domesticated.

\section{The doings of care - from dirt to daylight}

We often think about the more spurned animals of the greenhouse. We are provoked by the stick insects, the mealworms, the snails and those we can't discern with eyes, such as the bacteria and other microbes.

What does it take to take care for outcasts? What do the outcasts mean for care? 
One day there is some new bustle at the back of the greenhouse.

The terrariums of giant African snails have been cleaned.

Before they were on their own, covered with black slime and dirt, and their bodies looked disgusting through the glass.

Now they have their own caretakers, Sasha and his friend Misha.

Armi describes how eagerly the boys had taken the job.

'The snails are the most important critters in a way', she says.

'Without the snails and other decomposers, we would not thrive'.

The glass walls are bright now, and there is good-looking food to eat inside.

Sasha has taken the snails out from the terrariums.

He sprays them with water and gives them a bath, individually

cleaning them all over

'so that they would get a bit of celebration'.

The snails are reaching out from their shells,

and they come into daylight and show their antennas.

The three-dimensional analytical tool of care as maintenance, affect and ethics/politics can be turned around and around to create perspectives into yet new angles of how care works.

Above, storying about the biting little gerbil, with care as an analytic, enabled observing the emergence of caring knowledge (de la Bellacasa 2017: 18). On the other hand, the multidimensional notion of care complements the concepts of attunement (Despret, 2004) and charisma (Lorimer, 2007) and sheds light to the agential doings of caring relations. In the context of this research, we use the term 'greenhouse effect' to refer to these sometimes surprising doings. An example is storied above. A group of immigrant background boys, including Sasha and Dima, became devoted to the giant African snails, going to see them whenever they could, cleaning them and their terrariums and growing them beautiful plants to eat. We had previously thought of those animals as being the lowest in the unfolding hierarchy, the outcasts among the greenhouse animals based on their immediate level of nonhuman charisma (Lorimer, 2007) and scarce communication in the eyes of a human observer. The relations between the giant African snails and the kid bathing them suggest that there are no causal relations from presupposed charisma or perceived utility to humans to establishing caring relations, but that these relations are specific assemblages open to changes generated by care itself. Because care is 'a relationship that also creates relationality' (de la Bellacasa 2017: 161), it generates surprising world-makings. Cleaning the snails from dirt transforms their snailness, possibly affecting their microbiota. But how? We do not know, and once again, we are left with care as an uncertain, impure and non-innocent affair. 


\section{The rabbits have been set free! Troubles of multispecies childhoods}

One day, Tuure climbs on the balcony of the greenhouse

to install a GoPro camera with a wide-angle lens.

Watching the video taken from the bird's perspective, we see the greenhouse in a different light.

Almost no animals are visible, and all we see is ceilings of cages of various sizes.

We have thought about the greenhouse as a home of animals and plants

but is this a home or a jailhouse?

Our colleague is an animal rights activist.

Looking at photographs taken in the greenhouse she asks

'Is it OK to raise kids to think that it is OK to have animals in cages just for a human's sake'?

Energised by her activism,

I go about asking the children how they feel about having animals in cages.

They have not thought about it.

We don't know if it is just a coincidence

that shortly after this, one morning, we are told,

'The rabbits have been set free'!

That is, their cages have been opened and they are let to move freely around.

Earlier, they had been taken out for shorter periods,

but never the four of them at the same time.

This day becomes messy and violent.

Free coliving hurts.

At the end of the day, lumps of earth from fallen flower pots

and bunches of fur are everywhere.

The kids count the wounds,

at least the rabbits Leo and Taiga have got big scratches.

They conclude that after all the rabbits cannot handle their freedom, they blame the male hormones of the animals

as well as the environment that causes them stress.

The idea of forming one flock out of the four rabbits is abandoned.

In the multispecies co-living of the greenhouse, essentialised notions of the good, the right and the natural are constantly under debate. The above storied negotiation about the freedom of the rabbits highlights the controversial politics and ethics belonging to care. The question of rights is yet another issue that connects human children and animals, two categories positioned in need of protection. The rights discourse becomes complicated when thinking with care, because caring involves participants that are flesh and blood, and responding to each other in specific worlding encounters where details matter. Yet, these situated and detailed encounters are never apart from the more generic dilemmas: the commodification of 
life, the capturing of animals for humans' sake, for ends such as consumption, amusement and company, the related capitalist enterprises and the ways animals are differentiated in this regard.

Behind the glass walls of the greenhouse, there is the school dining room.

Today, as usual, there is meat and some vegetables for lunch.

In contrast, when one of the gerbils had died in the greenhouse,

and we asked Dima whether it now would be fed to Viljami the snake,

he was shocked:

'Of course not! That would be totally unethical'!

Viljami's food was kept in the deepfreeze in the biology class

white mice that came by mail, ordered from Germany.

In this article, we have drawn on the idea that humans could be defined through their relations to other species rather than through their differences from them (Grusin, 2015) and brought this idea into the domain of childhood studies while developing the concept of multispecies childhood. This concept, in order to be alive and useful, has to embrace the tensions and troubles of contemporary global existence. The theories of care offered us an analytic and a provocation towards attending to such tensions ranging from the ethics of establishing a rescue for homeless pets, the embodied and affective knowledge practices and socially just educational politics on the other hand, to the problems of pet industry, educational and other everyday practices that reinforce binary and unequal relationships between species, and the energy consumption needed for maintaining the greenhouse climate during the harshest winter months, when the temperature difference between outdoors and indoors arose up to 50 degrees Celsius, on the other. While we observed joy and affection, and listened to stories about practically mute children having become more talkative and confident after engaging with the greenhouse activities, our attention was repeatedly drawn to moments in which multispecies co-living hurts and generates conflicts. These troubles are the same troubles that the inhabitants of this globe share at a larger scale.

Haraway's notion of 'staying with the trouble' (2016) is a central ethico-political stance being quickly adopted throughout childhoodnature scholarship (Somerville, 2018) to the extent that it might be in the risk of turning into a buzzword. However, we find its political power in the situated approach that both Haraway and de la Bellacasa insist on. Haraway stated that details matter and that stories can help one to remember what they thought they knew, whereby 'a muscle critical for caring about flourishing gets (. . .) aerobic exercise' (2016: 116). Similarly, in this study, we have attempted to stay close to the details of the stories and bodies within child-animal caring relations situated in a specific greenhouse in our 
northern country. When presenting multispecies conceptualisations, however, we are moving onto a risky terrain. We fully follow Pedersen's and Pini's (2016) view that the contemporary turn in social sciences to more-than-human epistemology and methodology might be happening too considerably and too quickly. It is hard even to grasp the scale of the challenge, considering how phenomena such as politics or education so rarely are understood as anything else than human-only matters, or thinking about the taken-for-granted humancentred legacy defining all the concepts and notions related to research methodologies. One example of this anthropocentrism is that when talking about childhood, we usually refer to merely human childhood. Also, when engaging with caring relations through predominantly verbal activities of storytelling and article writing, it remains open, how other species than humans actually are involved. One attempt to respond to this issue is to insist on a relational ontology where individuals are understood as becomings, or rather becomings-with, and thus always 'more than one' (Manning, 2013). Another is to cultivate leaky methodologies, as we did in this article employing for example Haraway's bag lady storytelling approach and Despret's idea of visiting. The leaking bags of the storyteller can facilitate analytical movement across and beyond the persistent lines of binary thinking concerning both childhood and the relations between humans and other species. But these leaking bags could also be seen, borrowing from Malone, Duhn and Tesar (2018), as greedy for new theories and stories about contemporary multispecies existence shared by children and other than human animals.

\section{Acknowledgements}

We are deeply grateful for being given the possibility to share thoughts, stories and attunements with the participants of the study, human and other than human.

\section{Funding}

This research is part of the project Significant others - How animals matter as part of children's everyday life (AniMate), funded by The Emil Aaltonen Foundation. 


\section{References}

Barad K (2007) Meeting the universe halfway: Quantum physics and the entanglement of matter and meaning. Duke University Press: Durham \& London.

Bartos AE (2012) Children caring for their worlds: The politics of care and childhood. Political Geography, 31(3): 157-166.

Burke CL and Copenhaver JG (2004) Animals as people in children's literature. Language Arts 81(3): 205-213.

Cutter-Mackenzie A, Malone K and Barratt Hacking E (2018) Research Handbook on Childhoodnature. Springer International Handbooks of Education. Springer, Cham.

Finnish National Agency for Education (2014) Curriculum for Basic education. https://www.oph.fi/english/curricula and qualifications/basic education/curricula 201 $\underline{4}$ (retrieved the 21.7 .2018 )

Darling J and Van De Pijpekamp M (1994) Rousseau on the education, domination and violation of women. British journal of educational studies 42(2): 115-132.

de la Bellacasa MP (2017) Matters of care: Speculative ethics in more than human worlds. University of Minnesota Press.

Deleuze G and Guattari F (1987) A thousand plateaus: Capitalism and schizophrenia. Translated by B Massumi. University of Minnesota Press: Minneapolis, MN.

Despret V (2004) The body we care for: Figures of anthropo-zoo-genesis. Body \& Society: 10(2-3): 111-134.

Despret V (2016) What Would Animals Say If We Asked the Right Questions? Translated by B Buchanan. University of Minnesota Press.

Duhn I and Quinones G (2018) Eye-to-Eye with Otherness: A Childhoodnature Figuration. In: CutterMackenzie A, Malone K, Barratt Hacking E (eds) Research Handbook on Childhoodnature. Springer International Handbooks of Education. Springer, Cham.

Finnish National Agency for Education (2014) New national core curriculum for basic education. https://www.oph.fi/english/curricula_and_qualifications/basic_education/curricula_2014

Friesen $L$ (2010) Exploring animal-assisted programs with children in school and therapeutic contexts. Early Childhood Education Journal 37(4): 261-267.

Grusin R (2015) The nonhuman turn. University of Minnesota Press.

Haraway D (2004) The Haraway reader. Routledge: New York \& London.

Haraway D (2008) When species meet. University of Minnesota Press.

Haraway D (2015) A curious practice. Angelaki 20(2): 5-14.

Haraway DJ (2016) Staying with the trouble: Making kin in the Chthulucene. Duke University Press.

HundrEd. https://hundred.org/en

Kirksey S and Helmreich S (2010) The emergence of multispecies ethnography. Cultural anthropology 25(4): 545-576.

Lee N and Motzkau J (2011) Navigating the bio-politics of childhood. Childhood 18(1): 7-19. 
Lorimer J (2007) Nonhuman charisma. Environment and Planning D: Society and Space 25(5): 911932.

MacLure M (2013) Researching without representation? Language and materiality in post-qualitative methodology. International journal of qualitative studies in education 26(6): 658-667.

Malone K (2018) Re-turning Childhoodnature: A Diffractive Account of the Past Tracings of Childhoodnature as a Series of Theoretical Turns. In: Cutter-Mackenzie A, Malone K, Barratt Hacking E (eds) Research Handbook on Childhoodnature. Springer International Handbooks of Education. Springer, Cham.

Malone K, Duhn I and Tesar M (2018) Greedy Bags of Childhoodnature Theories. In: CutterMackenzie A, Malone K, Barratt Hacking E (eds) Research Handbook on Childhoodnature. Springer International Handbooks of Education. Springer, Cham.

Manning E (2013) Always more than one: Individuation's dance. Duke University Press.

Myers JrOE (2013) Children, animals, and social neuroscience: Empathy, conservation education, and activism. In: Bekoff $\mathrm{M}$ (ed) Ignoring nature no more: The case for compassionate conservation. University of Chicago Press, pp. 271-285.

Nxumalo F and Pacini-Ketchabaw V (2017) 'Staying with the trouble' in child-insect-educator common worlds. Environmental Education Research, 23(10): 1414-1426.

Pedersen $\mathrm{H}$ (2010) Is 'the posthuman' educable? On the convergence of educational philosophy, animal studies, and posthumanist theory. Discourse: Studies in the Cultural Politics of Education 31(2): 237-250.

Pedersen $\mathrm{H}$ and Pini B (2017) Educational epistemologies and methods in a more-than-human world. Educational Philosophy and Theory 49(11): 1051-1054.co-eveolving

Pickering A (2005) Asian eels and global warming: A posthumanist perspective on society and the environment. Ethics \& The Environment 10(2): 29-43.

Prout A (2011) Taking a step away from modernity: Reconsidering the new sociology of childhood. Global studies of childhood 1(1): 4-14.

Rautio P (2013) Children who carry stones in their pockets: On autotelic material practices in everyday life. Children's Geographies, 11(4), 394-408.

Rautio P (2017) Thinking about life and species lines with Pietari and Otto (and garlic breath). TRACE.: Finnish Journal for Human-Animal Studies 3: 94-102.

Rautio P and Leinonen RM (2018) Hamsters and children - The sidekick family members? Paper presented at Childhood2018 Conference, the 8.5.2018, Jyväskylä, Finland.

Sampson TD (2012) Virality: Contagion theory in the age of networks. University of Minnesota Press.

Somerville M (2018) Posthuman Theory and Practice in Early Years Learning. In: Cutter-Mackenzie A, Malone K, Barratt Hacking E (eds) Research Handbook on Childhoodnature. Springer International Handbooks of Education. Springer, Cham.

Spannring R (2015) I and animal thou. Perspectives for educational theory. Society and Animals 23(6): 613-629. 
Tammi T., Rautio P., Leinonen RM., Hohti R. (2018) Unearthing Withling(s): Children, Tweezers, and Worms and the Emergence of Joy and Suffering in a Kindergarten Yard. In: Cutter-Mackenzie A., Malone K., Barratt Hacking E. (eds) Research Handbook on Childhoodnature. Springer International Handbooks of Education. Springer, Cham.

Taylor A (2011) Reconceptualizing the 'nature' of childhood. Childhood 18(4): 420-433.

Taylor A and Pacini-Ketchabaw V (2017) Kids, raccoons, and roos: awkward encounters and mixed affects. Children's Geographies 15(2): 131-145.

Thompson KL and Gullone E (2003) Promotion of empathy and prosocial behaviour in children through humane education. Australian Psychologist 38(3): 175-182.

Tronto JC (1993) Moral boundaries: A political argument for an ethic of care. Psychology Press.

Weaver JA and Snaza N (2017) Against methodocentrism in educational research. Educational Philosophy and Theory 49(11): 1055-1065. 